\title{
Purification of a novel protease enzyme from kesinai plant (Streblus asper) leaves using a surfactant-salt aqueous micellar two-phase system: a potential low cost source of enzyme and purification method
}

\begin{abstract}
Serine protease from kesinai leaves was purified for the first time by a surfactant-polymer aqueous micellar two-phase system. The effectiveness of different types and concentrations of non-ionic surfactants (Pluronic series and X-114) on the partitioning behaviour of the protease was evaluated. The results showed that the enzyme preferentially partitioned into the bottom surfactant-rich phase, while the hydrophilic amino acid preferred the top aqueous phase. This distribution of the enzyme is due to the hydrophobic interaction of the serine protease with the hydrophobic lid of the micelle core in the bottom phase. The influence of different types of salts (K2SO4, $\mathrm{KH} 2 \mathrm{PO} 4, \mathrm{KCl}$ and $\mathrm{KNO} 3$ ) on the purification and selectivity of the enzyme was determined. The protease partitioning in the bottom phase increased in the presence of KNO3, which confirmed that the salt was able to improve the protein solubility in bottom phase and increase the hydrophobic interaction between the two phases. In addition, the protease from the bottom phase was re-extracted to a new aqueous phase solution to remove and recycle the surfactant. Addition of potassium thiocyanate led to the partitioning of the enzyme in top aqueous phase due to high ionic strength of $\mathrm{SCN}-$, which forced the lighter micellar phase toward the upper position of the system. A high purification factor (10.3) and yield of $92 \%$ of the enzyme were achieved in a solution of $31 \%$ of Pluronic L61 using $0.3 \% \mathrm{KNO} 3$ and $50 \%$ crude feedstock at $\mathrm{pH} 7.0$.
\end{abstract}

Keyword: Purification; Protease enzyme; New aqueous micellar phase solution; Kesinai leaves; Partition behavior; Phase recycling 